\title{
Comparative anatomy of the caudal fin (pinna caudalis) Tor douronensis (Valenciennes, 1842) and Tor soro (Valenciennes, 1842)
}

\author{
Yusrizal Akmal ${ }^{1}$, Ilham Zulfahmi ${ }^{2}$,, Muliari Muliari ${ }^{1}$, Andi Iqbal Burhanuddin ${ }^{3}$, Budimawan Budimawan ${ }^{3}$, Yeni $^{2}$ \\ Dhamayanti $^{4}$, Rindhira Humairani ${ }^{1}$, Irfannur Irfannur $^{1}$, Rinaldi Rinaldi ${ }^{1}$ \\ ${ }^{1}$ Department of Aquaculture, Faculty of Agriculture, Universitas Almuslim, Bireuen, Indonesia \\ ${ }^{2}$ Department of Fisheries Resources Utilization, Faculty of Marine and Fisheries, Universitas Syiah Kuala, Banda Aceh, Indonesia \\ ${ }^{3}$ Faculty of Marine Science and Fisheries, Hasanuddin University, Sulawesi Selatan, Indonesia \\ ${ }^{4}$ Department of Veterinary Anatomy, Faculty of Veterinary Medicine, Universitas Airlangga, Indonesia
}

\begin{abstract}
Tor douronensis and Tor soro were two of the four species of the Tor genus that live in Indonesian waters. However, studies related to the skeleton of these two fish are still rarely disclosed. The aim of this study compared the morphology of the caudal-fin (pinna caudalis) T. douronensis and T. soro. The research stages include sample preparation, making skeleton preparations, image analysis, and identification of skeleton terminology. T. douronensis fish were collected from the waters of the Pagar Alam area, Lahat Regency, South Sumatra, while T. soro was collected from the waters of Bukit Lawang, Bohorok District, Langkat Regency, North Sumatra Province. The caudal-fin (pinna caudalis) is part of the ossa urostylus which produces optimal hydrodynamic propulsion. The caudal-fin (pinna caudalis) Genus Tor is part of the ossa urostylus which is composed of 31 caudal-fin rays (pinnae), six hypural bones, parhypural, pleurostylus, epural, and uroneuralis. The ventral part of $T$. douronensis and $T$. soro is composed of the parhypural, and the $1^{\text {st }}$ and $2^{\text {nd }}$ hypural bones. T. douronensis had a parhypural bone that was more prominent and separates from the spina hemalis compared to $T$. soro. The dorsal part was composed of the $3^{\text {rd }}$ hypural bones to $6^{\text {th }}$ hypural, in T. soro the hypural bone was fused with cartilage. Os pleurostylus $T$. douronensis had a more prominent shape than $T$. soro and there was enlargement in the posterior part. The $3^{\text {rd }}$ and $4^{\text {th }}$ hypural bones on $T$. soro had the largest size. The $T$. soro had three spina neuralis and three spina hemalis to support the rays of the tail. The bones that composed the caudal-fin of T. douronensis and T. soro were relatively similar to those of some fish from the family Cyprinidae. The results of this study could be used as an alternative to identify $T$. douronensis and $T$. soro from the skeleton.
\end{abstract}

\section{Introduction}

Although many studies of the fish skeleton morphology had been carried out, the nomenclature of the bones that make up the skeleton, especially the head, still shows a high level of inconsistency so that it had an impact on the bias of the bone constituent data for different fish species (Bogutskaya et al. 2008) [1]. Fish of the same genus generally have almost similar external morphological characteristics so that it was sometimes difficult to distinguish, therefore additional analysis was needed to be able to identify differences between these species, including through skeleton comparisons. Several studies on skeleton comparisons of several fish families had been carried out previously, including fish from the Nemacheilidae family [2], Characidae family [1], Cichlidae family [3], and Zoarcoidei family [4].

The limb bones of fish were composed of fins supported by skeletal and controlled by muscles [5]. According to Standen, fish depend $20 \%$ of their movement and propulsion on their fins [6]. Generally, fish have two paired fins and three single fins. Paired fins consist of pectoral (pinna pectoralis) and pelvic fins (pinna pelvis), while single fins consist of dorsal (pinna dorsalis), anal (pinna analis), and caudal fin (pinna caudalis) [7][8]. The caudal-fin had optimal hydrodynamic propulsion and the shape could also indicate the swimming habits of fish [9]. In some fish species, the shape of the fins and the rays of the fins are modified from the general form and had several other additional functions, such as sperm distribution and attachment tools [9].

Tor douronensis and Tor soro were two of the four species of the Tor genus that live in Indonesian waters. However, the study related to the osteology of these two fish are still rarely disclosed. The caudal-fin was one of the body parts of the fish with striking differences between species in the same genus in addition to weber bones [10]. The aims of this study was to compare the caudal-fin (pinna caudalis) of $T$. douronensis and T. soro. 


\section{2}

\section{Materials and Methods}

\subsection{Location and Sample Preparation}

The research stages include sample preparation, making skeleton preparations, image analysis, and identification of the skeleton terminology. Making skeleton preparations at the Aquaculture Laboratory, Aquaculture Study Program, Faculty of Agriculture, Almuslim University. The fish was used in this study were obtained by direct capture from fish collectors. Sample of the fish have a minimum weight, at least 2 $\mathrm{kg}$ with a length $30-50 \mathrm{~cm}$. $T$. douronensis were collected from the waters of the Pagar Alam area, Lahat Regency, South Sumatra, while T. soro was collected from the waters of Bukit Lawang, Bohorok District, Langkat Regency, North Sumatra Province. 10 sample for each type of the fish were collected. The fish are then preserved using ice and transported to the laboratory.

\subsection{Caudal fin preparation}

The procedure of the preparation tail was based on Zulfahmi et al. 2020[11]. Tail's fish was cutting located at the posterior aspect of the last centrum of the ossa vertebrae caudales. The separated fish fins are then soaked in hot water at a temperature range of 80$90^{\circ} \mathrm{C}$ until the muscle and connective tissue are blistered and white. Soaking in hot water was done carefully so that the bones did not become brittle. Preparation of fish skeleton preparations was done physically and chemically. Physically, fish scales are removed using a knife or tweezers and then doused with hot water until the muscles scald and turn white. The chemical stage begins with immersing the skeleton sample into formalin $10 \%$. Specimens were transferred to $70 \%$ ethanol solution to remove stains on the skeleton [12].

\subsection{Image editing and Identification of Skeleton Terminology}

The digital image of the fish was taken from the lateral direction with Canon EOS 750D. After that, it was analyzed with the Adobe Photoshop CS6 software and then presented with a table and image.

\section{$3 \quad$ Results and Discussion}

The cauda fin (pinna caudalis) of the Tor's Genus was part of the urostylus bones. These bones had 31 of the cauda fin (pinnae), six of the hypural bones, pleurostylus, epural, and uroneuralis bone. The ventral side of the $T$. douronensis and $T$. soro is composed of parhypural bone, and $1^{\text {st }}-2^{\text {nd }}$ hypural bones. The parhypural bone of the $T$. douronensis more prominent than T. soro. The parhypural bone of the T. soro fused with cartilage bone and enlargement at the posterior part.

The dorsal part was composed of the $3^{\text {rd }}$ to $6^{\text {th }}$ hypural bones, and in $T$. soro the hypural bone was fused with cartilage. Os pleurostylus $T$. douronensis was a more prominent shape than $T$. soro, and there was an enlargement in the posterior part. The $1^{\text {st }}, 3^{\text {rd }}$, and $4^{\text {th }}$ hypural bones of the $T$. soro had the largest size, while the $5^{\text {th }}$ and $6^{\text {th }}$ hypural was the smallest size. The $2^{\text {nd }}$ hypural bone of $T$. douronensis was the largest one, while the $6^{\text {th }}$ hypural was the smallest size. T. soro had three neural spines and three haemal spines to support the rays of the caudal fin (Figure 1.)

The bones that make up the fins of the tail of $T$. douronensis and $T$. soro are relatively the same as some fish from other Cyprinidae families, such as Ischikauia steenackeri, Alburnus amirkabiri, Cyprinion milesi, and Barbus cyri [14][15][16][17]. However, the Barbus cyri fish had a larger hypural bone size than the parhypural bone, compared to that T. soro fish.
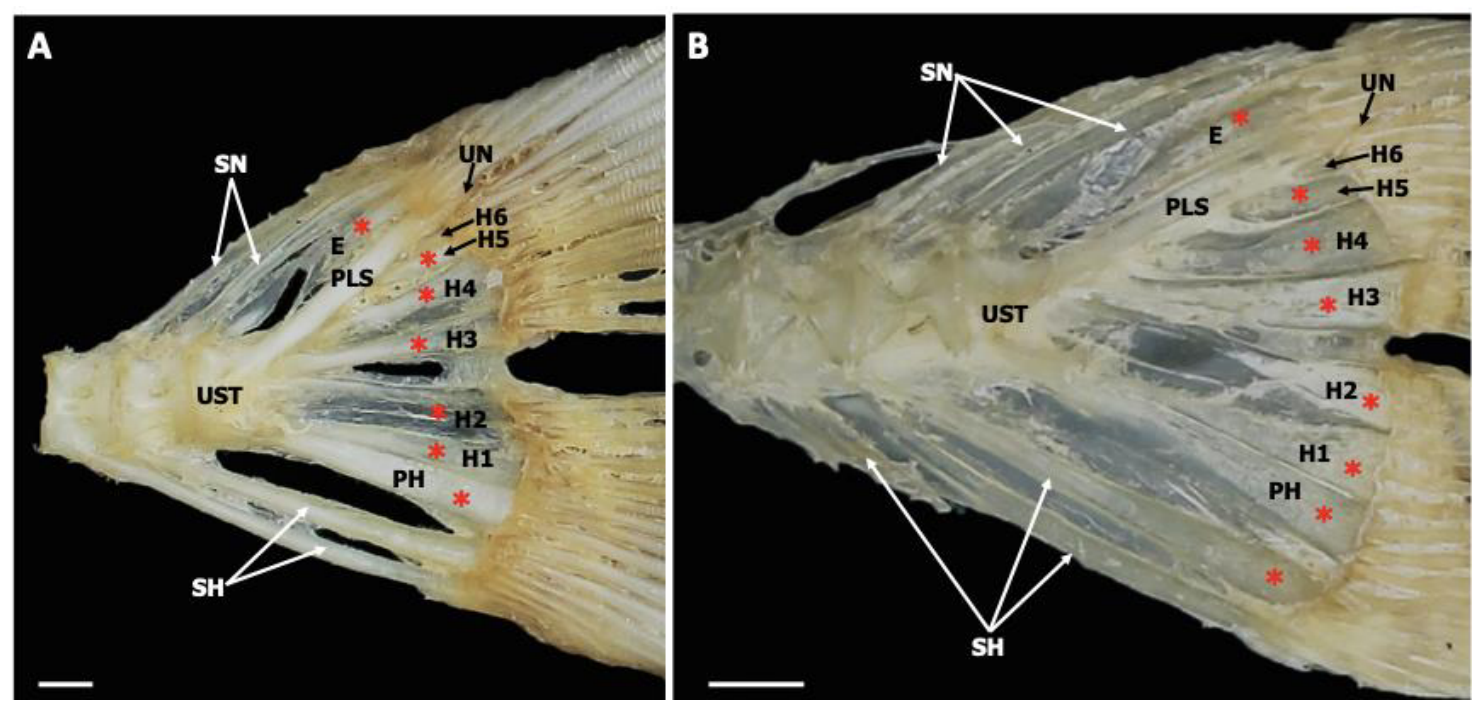

Fig. 1. Pinna caudalis lateral view of T. douronensis (A) and T. soro (B). Description: arcus neuralis (AN); Centrum (C); Os epural (E); Os hypural (H); Os parhypural (PH); Os pleurostylus (PLS); Os preural urostylus (PU); spina haemalis (SH); spina neuralis (SN); Os uroneuralis (UN); Ossa urostylus (UST). Bar scale: $0.5 \mathrm{~cm}$. 
Table 1. Comparative morphology of the caudal fin (pinna caudalis) T. douronensis and T. soro

\begin{tabular}{|l|l|l|l|l|}
\hline No & \multicolumn{1}{|c|}{ Bone name } & view & \multicolumn{1}{|c|}{ T. douronensis } & \multicolumn{1}{c|}{ T. soro } \\
\hline 1 & Os parhypural & Lateral & $\begin{array}{l}\text { The shape more prominent and slim, } \\
\text { separated from spina hemalis }\end{array}$ & $\begin{array}{l}\text { The shape thinner, enlargement at the } \\
\text { posterior part, and fused to spina } \\
\text { hemalis }\end{array}$ \\
\hline 2 & Os hypural 1 & Lateral & Slim and sturdy & Enlargement at the posterior part \\
\hline 3 & Os hypural 2 & Lateral & Slim and thin & $\begin{array}{l}\text { Slim and short } \\
\text { pide and enlargement at the posterior }\end{array}$ \\
\hline 5 & Os hypural 3 & Lateral & Slim and sturdy & $\begin{array}{l}\text { Had the largest size with indistinct } \\
\text { boundaries with the } 5^{\text {th }} \text { hypural O }\end{array}$ \\
\hline 6 & Os hypural 4 & Leteral & $\begin{array}{l}\text { Had a clear boundary with the } 5^{\text {th }} \\
\text { hypural bone }\end{array}$ & Wide and long \\
\hline 7 & Os hypural 6 & Leteral & Not wide and short & $\begin{array}{l}\text { Indistinct boundry with the } 5^{\text {th }} \text { hypural } \\
\text { bone }\end{array}$ \\
\hline 8 & Neural spines & Lateral & $\begin{array}{l}\text { Clearly boundry with the } 5^{\text {th }} \text { hyoural } \\
\text { bone }\end{array}$ & $\begin{array}{l}\text { 2 spines } \\
\text { others }\end{array}$ \\
\hline 9 & Haemal spines & Lateral & 2 spines & 3 spines \\
\hline
\end{tabular}

T. douronensis had more tail fin rays than Petrocephalus simus (family Mormyridae) and lower than Oreochromis lorenzoi fish (family Cichlidae) [18][19]. The caudal fin rays of $T$. douronensis and $T$. soro fish were divided into two parts, namely the ventral fin rays and the dorsal fin rays with sharp angles. According to Lauder, the function of the ventral caudal fin rays was more dynamic than the dorsal [20]. The shape of the pointed tail fin with long fingers on the Keureling fish indicated that the fish was capable of swimming at high speeds [21]. The caudal fin was one of the bones that had a high variation between species compared to the bones that make up other body parts.

\section{Conclusion}

The caudal fin (pinna caudalis) of $T$. douronensis and $T$. soro fish was part of the ossa urostylus. The urostylus bone was composed of 31 caudal-fin rays (pinnae), six hypural bones, parhypural, pleurostylus, epural, and uroneuralis bones. The ventral parts of $T$. douronensis and $T$. soro were composed of the parhypural bone and the $1^{\text {st }}$ and $2^{\text {nd }}$ hypural bones. $T$. douronensis had a parhypural bone that was more prominent and separated from the haemalis spine than T. soro. The dorsal part was composed of the $3^{\text {rd }}$ to $6^{\text {th }}$ hypural bones. The hypural bone of the $T$. soro fused with cartilage. The shape pleurostylus bone $T$. douronensis was more prominent than $T$. soro, and there was an enlargement in the posterior part. The size of the $3^{\text {rd }}$ and $4^{\text {th }}$ hypural bones of the $T$. soro was the largest. The $T$. soro had three neural spines and three haemal spines to support the rays of the caudal fin. The results of this study could be used as an alternative to identify $T$. douronensis and $T$. soro by osteology.

Acknowledgments. We would like to thank the Ministry of Education, Culture, Research, and Technology Indonesia for funding this research through the Penelitian Kerjasama Antar Perguruan Tinggi/PKPT scheme (Number: B/112/E3/RA.00/2021 and Agreement/Contract Number: 173/ E4.1/AK.04.PT/2021，035/LL13/AKA/LT /2021, 140/LPPM-Umuslim/KP/2021).

\section{References}

1. Y. Akmal, $\mathrm{Y}$ Dhamayanti, \& E. Paujiah. Osteocranium of Tor tambroides (Cypriniformes: Cyprinidae) from Tangse River, Aceh, Indonesia. Biodiversitas Journal of Biological Diversity, 21(2) (2020).

2. P. Mafakheri, S. Eagderi, H. Farahmand MousaviSabet H. Osteological structure of Kiabi loach, Oxynoemacheilus kiabii (Actinopterygii: Nemacheilidae). Iranian Journal of Ichthyology, 1(3): 197 - 205 (2015).

3. K. Dierickx, W. Wouters, \& W. Van Neer. Comparative osteological study of three species of distinct genera of Haplotilapiini (Cichlidae). Cybium, 41(3): 223-235 (2017).

4. EJ. Hilton \& NJ. Kley. Osteology of the Quillfish, Ptilichthys goodei (Perciformes: Zoarcoidei: Ptilichthyidae). Copeia, 2005(3): 571-585 (2005).

5. EJ. Hilton. The Skeleton Bony Fish Skeleton. Elsevier Inc. All rights reserved, Virginia Institute of Marine Science, Gloucester Point, VA, USA. 434-436p (2011).

6. EM. Standen. Buoyancy, Locomotion, and Movement in Fishes, Paired Fin Swimming. Elsevier Inc, McGill University, Canada. 564p (2011).

7. P. Lőw, K. Molnár, G. Kriska. Atlas Of Animal Anatomy And Histology. Springer, pp17 (2016).

8. J. Cardeira, R. Valles, G. Dionısio, A. Estevez, E. Gisbert, P0.00000 Pousao-Ferreira, ML. Cancela, PJ. Gavaia. Osteology of the axial and appendicular skeletons of the meagre Argyrosomus regius (Sciaenidae) and early skeletal development at two rearing facilities. Journal of Applied Ichthyology, 28(12): 464-470 (2012).

9. Y. Akmal, \& MF. Rahardjo. Morphology of appendicular skeleton of the Thai mahseer's Tor tambroides (Bleeker, 1854). Jurnal Iktiologi Indonesia, 18(3), 261-274 (2018). 
10. I. Zulfahmi, Y. Akmal, M. Radhi, M. Hidayat, \& M. Muliari. Comparative osteology of Tor tambroides (Bleeker, 1854) and Tor tambra (Valenciennes 1842) vertebral column (ossa vertebrae). Jurnal Iktiologi Indonesia, 20(3), 235249 (2020).

11. I. Zulfahmi, \& Y. Akmal. Komparatif Osteologi Tor tambroides \& Tor tambra. PT Penerbit IPB Press (2020).

12. WR. Taylor, \& CC. Van Dyke. Revised procedures for staining and clearing small fishes and other vertebrates for bone and cartilage study. Cybium, 9(2): 107-119 (1985).

13. I. Zulfahmi, Y. Akmal, Muliari. Osteologi Ikan Keureling (Tor tambroides). IPB Press, Bogor. Pp. 107 (2019).

14. H. Takeuchi K. Hosoya. Osteology of Ischikauia steenackeri (Teleostei: Cypriniformes) with comments on its systematic position. Ichthyological Research, 58(1): 10-18 (2011).

15. P Jalili, S. Eagderi, M. Nasri, H. Mousavi-Sabet. Descriptive osteology study of Alburnus amirkabiri (Cypriniformes: Cyprinidae), a newly described species from namak lake basin, central of Iran. Bulletin of the Iraq Natural History Museum, 13(4): 51-62 (2015a).

16. P. Jalili, S. Eagderi, N. Nikmehr, Y. Keivany. Descriptive osteology of Barbus cyri (Teleostei: Cyprinidae) from southern Caspian Sea basin. Iranian Journal of Ichthyology, 2(2): 105-112 (2015b).

17. M. Nasri, S. Eagderi, H. Farahmand. Descriptive and comparative osteology of Bighead Lotak, Cyprinion milesi (Cyprinidae: Cypriniformes) from southeastern Iran. Vertebrate-zoology, 66(3): 251-260 (2016).

18. EJ. Hilton. Comparative osteology and phylogenetic systematics of fossil and living bonytongue fishes (Actinopterygii, Teleostei, Osteoglossomorpha). Zoological Journal of the Linnean Society, 137(1): 1-100 (2002).

19. G. Carnevale, C. Sorbini, W. Landini. Oreochromis lorenzoi, a new species of tilapiine cichlid from the late Miocene of central Italy. Journal of Vertebrate Paleontology, 23(3): 508516 (2003).

20. GV. Lauder. Function of the caudal fin during locomotion in fishes: kinematics, flow visualization, and evolutionary patterns. Integrative and Comparative Biology,40(1):101122 (2000).

21. JA. Walker, MW. Westneat. Performance limits of labriform propulsion and correlates with fin shape and motion. The Journal of Experimental Biology, 205: 177-187 (2002). 